\title{
bistoria mediebal
}

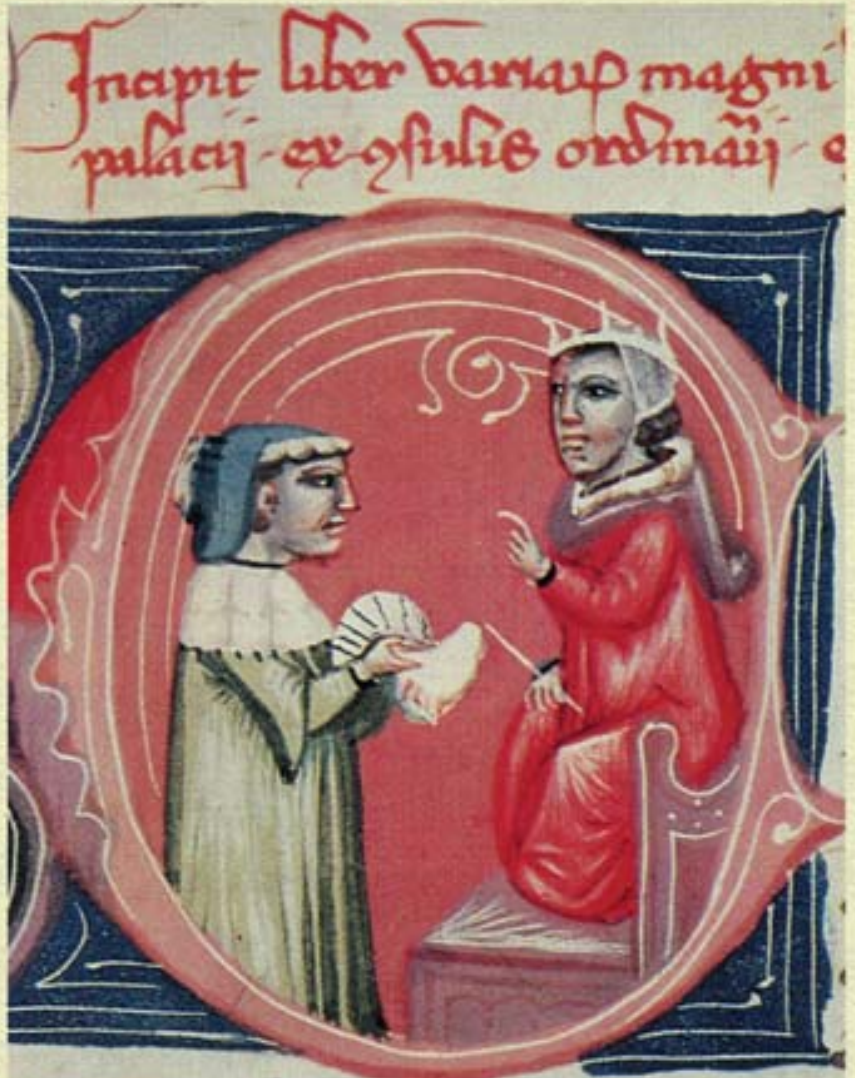

vorr corpro refigene Prad poptive raters meons in

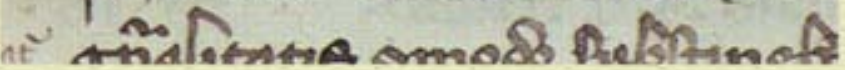

anales de la unibersidad de alicante 13

Departamento de Historia Medieval / $\mathrm{N}^{0} 13 /$ 2000-2002 
Depósito legal: A-477-1984

ISSN: 0212-2480

Fotocomposición e impresión:

COMPOBELL S.L. MURCIA

Reservados todos los derechos. No se permite reproducir, almacenar en sistemas de recuperación de la información ni transmitir alguna parte de esta publicación, cualquiera que sea el medio empleado -electrónico, mecánico, fotocopia, grabación, etc.-, sin el permiso previo de los titulares de los derechos de la propiedad intelectual.

Estos créditos pertenecen a la edición impresa de la obra

Edición electrónica:

El Espagrafic 


\section{ANALES DE LA UNIVERSIDAD DE ALICANTE HISTORIA MEDIEVAL}

Director: José HINOJOSA MONTALVO

Coordinador del número: Juan Antonio BARRIO BARRIO

Comité de Redacción:

Juan Antonio BARRIO BARRIO
José Vicente CABEZUELO PLIEGO
José HINOJOSA MONTALVO
Pedro Carlos PICATOSTE NAVARRO

Comité Científico:

María Teresa FERRER i MALLOL

Manuel GONZÁLEZ JIMÉNEZ

David IGUAL LUIS

Juan Francisco JIMÉNEZ ALCÁZAR

Miguel Ángel LADERO QUESADA

Ángel Luis MOLINA MOLINA

Germán NAVARRO ESPINACH

Flocel SABATÉ I CURULL

Esteban SARASA SÁNCHEZ

Yon TOV ASSIS

\section{SECRETARIADO DE PUBLICACIONES \\ UNIVERSIDAD DE ALICANTE}




\title{
ANALES DE LA UNIVERSIDAD DE ALICANTE HISTORIA MEDIEVAL
}

\author{
José Manuel Nieto Soria
}

Fragmentos de ideología política urbana en la castilla bajomedieval 
Índice

\section{Portada}

\section{Créditos}

Fragmentos de ideología política urbana en la castilla bajomedieval

1. Imágenes políticas en las cartas de hermandad entre concejos (ca. 1280-1350)

2. La potenciación del gesto en el discurso político urbano (ca. 1350-1420) .......................................... 15

3. El absolutismo regio como polarizador del discurso urbano (1420-1454)

4. La coexistencia de discursos urbanos

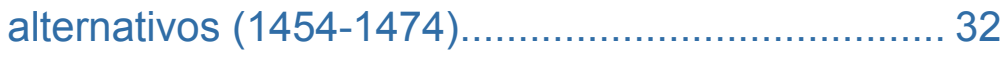

5. La ciudad como sujeto de mitificación......................46

6. Conclusiones: un diálogo de exhibición y de ocultación 51 


\section{Fragmentos de ideología política urbana en la castilla bajomedieval}

José Manuel Nieto Soria Universidad Complutense de Madrid

n un trabajo reciente (nota 1) se ofrecía una de las pri-
meras visiones de conjunto, en sus diversas facetas
expresivas y en sus distintas posibilidades en cuanto a fuentes de información, de lo que había sido la actividad política de las ciudades bajomedievales en la Corona de Castilla en clave de iniciativas de índole propagandística y legitimadora, prestando atención preferente a los rasgos de tal fenómeno en el contexto del siglo XV. Otro tipo de aproximación a la dimensión ideológica de la vida política urbana en la Castilla bajomedieval ha venido por la vía de su aproximación desde la perspectiva de la actividad ideológico-política promovida desde la monarquía (nota 2), que encontraba en las ciudades del reino un referente y un escenario de relevante 


\section{Fragmentos de ideología política urbana en la castilla bajomedieval}

importancia. Por último, la ciudad fue el marco por excelencia de la práctica ceremonial de significado político, por lo que también ha existido algún interés específico por esta línea de investigación con relación a las ciudades castellanas, tanto desde la una perspectiva general del reino (nota 3), como particular con relación a alguna ciudad concreta (nota 4).

La perspectiva, sin embargo, desde la que se aborda el tema propuesto en el título de este trabajo responde a objetivos algo distintos, si bien, en cualquier caso, bastante modestos. Se trata de llevar a cabo un recorrido cronológico entre fines del siglo XIII y del siglo XV en el que, a partir de algunos textos de origen concejil (nota 5), se pueda ir percibiendo la recepción y aplicación de conceptos e imágenes de relieve político y la elaboración de argumentaciones destinadas generalmente a sustentar aspiraciones de poder que, en definitiva, permitan, aunque sea de un modo necesariamente fragmentario, establecer alguna forma de aproximación a lo que serían referentes significativos de la fundamentación ideológica del poder concejil, planteados de forma predominante para proveerlo de sustento argumentativo en sus tensiones con otros poderes alternativos como, será el caso preferente del poder real, así como también del poder nobiliario. 
Se trata, en definitiva, de una aproximación exploratoria a un terreno aún carente de una cartografía precisa, en el que, por tanto, se imponen las cautelas y los tanteos propios de una viaje de reconocimiento, mediante el que se pretende dar otro paso en el proceso de incorporación del mundo concejil a un ámbito en el que todavía no acaba de tener toda la presencia e importancia historiográfica que le debería corresponder, como es el de la historia de las ideologías políticas en el transito del medievo a la modernidad.

\section{Imágenes políticas en las cartas de hermandad entre concejos (ca. 1280-1350)}

Consideradas en la actualidad las hermandades concejiles de fines del siglo XIII y de comienzos del XIV como «enérgicos movimientos de resistencia frente a una tendencia cada vez más vigorosa que impulsa la unificación de los sistemas jurídico y político» (nota 6), han sido objeto de una amplia diversidad de aproximaciones, ya desde la historiografía decimonónica hasta la más reciente, en las que se ha tratado de definir contextos, motivaciones y significados, permitiendo la complejidad de tal fenómeno enfocarlo una y otra vez desde nuevas perspectivas interpretativas, lo que ha hecho que se convierta en un tema siempre abierto al debate (nota 7). Lo cierto es que, desde la óptica que aquí interesa, aquélla que 


\section{Fragmentos de ideología política urbana en la castilla bajomedieval}

se refiere a la enunciación de principios de ideología política, no deja de ser en alguna medida fructífera la revisión de la documentación relacionada con dichas hermandades, así como de otra susceptible de conectarse con ésta y, todo ello en un contexto en el que, en general, la documentación de origen concejil no se caracterizaba precisamente por la amplitud de sus elucubraciones teórico-políticas.

Ya en documentación concejil próxima a la aparición de las primeras hermandades concejiles aparecen alusiones de relieve teórico-político que no dejan de tener algún relieve cuando se ponen en relación con las distintas cartas de hermandad. En tal sentido cabe aludir a la expresión «todos abenidos» como muy característica de textos concejiles en los que se expresaba la toma de algún acuerdo (nota 8) y, mediante la cual, se invocaba tanto lo que podría interpretarse como un fundamento de legitimidad, como la esencia de la fuerza que el concejo precisaba a la hora de hacer efectiva la iniciativa tomada. Además, a la vez que el concejo se definía como diverso en sí mismo, aludiendo a la presencia de diversos estados en su seno, haciendo particular diferenciación entre aquéllos que pertenecían a la villa y los que pertenecían a las aldeas, esa voluntad de unidad integradora que quedaba manifiesta en la expresión antes señalada al- 
canzaba aún figura más precisa en una cierta forma de concepción corporativa, mediante la que se quería mostrar a la ciudad y sus villas como un cuerpo armónico comprometido con un proyecto común (nota 9).

Por otra parte, mientras que se expresaba la conciencia de la capacidad de aportación significativa de las acciones de un concejo concreto al "endereçamiento de toda la tierra», también se apuntaba como objetivo omnipresente, por lo que se refería a las relaciones con la monarquía, la conservación de los fueros, privilegios y costumbres disfrutados en reinados anteriores (nota 10), con lo que se incidía en ese problema medular al que se aludía antes, el de la resistencia, en definitiva, se ponía el énfasis en un proceso que se consideraba como perjudicial a los intereses concejiles de rápida unificación del sistema jurídico y político contrario a la supervivencia de las peculiaridades jurídicas y políticas locales. A ello se unía, además, la toma de conciencia de que la ciudad poseía unas aspiraciones en cuya realización se ventilaba "toda nuestra pro y toda nuestra honra», lo que definía en términos conceptuales lo que se presentaba como factor de movilización básico en su proceso de reivindicación política (nota 11). 


\section{Fragmentos de ideología política urbana en la castilla bajomedieval}

Estos referentes conceptuales que se acaban de señalar formaban parte del enunciado documental de origen concejil característico allá por los años ochenta del siglo XIII, y no dejaron de tener reflejo significativo en las cartas de hermandad que se fueron formalizando a partir de 1282, lo que, en definitiva, nos sitúa ante la evidencia de que, en el plano de las formulaciones ideológicas, las hermandades concejiles no representaron una argumentación novedosa con relación a referentes ideológicos de uso concejil común por aquellos años, sino sólo la articulación institucional de conceptos políticos que ya estaban en presencia en el debate político en torno al ejercicio del poder urbano en los años inmediatamente anteriores al comienzo de tales hermandades, lo que no impide que la entidad política alcanzada por el propio movimiento concejil estructurado en torno a las hermandades exigiera de razonamientos de más vuelo, tal como se verá, pero siempre partiendo de la raíz de estas otras argumentaciones básicas recién señaladas.

Esta necesidad de otras argumentaciones de mayor relieve político viene impuesta, por de pronto, por el hecho de que, el propio carácter político que definía a la hermandad exigía de la toma de posición de ésta con respecto al poder real. En este sentido, a partir de las cartas de hermandad, se revela 
una actitud típica que supone el que la hermandad concejil se presenta como testimonio de la lealtad de las ciudades al rey, pero de una lealtad condicionada, incompatible con cualquier forma de sumisión y que, en consecuencia, abría un espacio político específico a las ciudades del reino para definir unas ciertas líneas políticas particulares coherentes con ese criterio de lealtad condicionada (nota 12). Tal criterio se resumía en el principio del respeto necesario de los reyes hacia los privilegios de las ciudades, de suerte que, si los reyes actuaran contra estos privilegios, las ciudades deberían recurrir al propio monarca para que lo enmendase, y si no resolviese en consecuencia de acuerdo con la propuesta de las ciudades, la hermandad estaría legitimada para ir contra el rey.

Tal criterio, que como se acaba de señalar, puede comprobarse en los mismos comienzos de este movimiento concejil, ya en 1282 , no deja de verse matizado a partir de lo que era la visión del mismo desde la perspectiva de las ciudades que en el contexto de la sublevación del infante don Sancho permanecieron fieles al rey Alfonso X. Así, el concejo de Sevilla, al dirigirse al de Murcia para solicitar su apoyo a la formación de una hermandad en defensa de este monarca, se declaró como actuando "a seruiçio de Dios et de nuestro señor el 


\section{Fragmentos de ideología política urbana en la castilla bajomedieval}

rey, et a pro et a guarda del et de uso et de nos», es decir, tomando esa opción de sumisión sin reservas, antitética de la planteada por los concejos hermanados, puesta en cuestión por éstos, a los que se acusa por los sevillanos de protagonizar una "grant falsedad» (nota 13).

Es, seguramente, ese criterio de lealtad condicionada que se halla en el origen de la hermandad general que se establece en 1295, en los comienzos de la minoridad de Fernando IV, lo que motiva que los concejos se consideren obligados a ejercer un cierta forma de tutela sobre el reino en un contexto de desgobierno (nota 14), considerando que tienen una responsabilidad particular con respecto a todo el reino en orden a garantizar su «pro e guarda» (nota 15). Tal planteamiento puede tener una lectura que va más allá de lo puramente retórico, pues, en definitiva, al reivindicar para sí los concejos, a través de la hermandad, esa función de tutela de hecho, se situaban, por lo que se refería a sus pretensiones de influencia política, en ese contexto de desgobierno, en una posición, cuando menos, equiparable a la de los propios tutores reales, lo que podía justificar con respecto a éstos un derecho de negociación entre iguales.

De este modo, la ausencia de gobierno regio efectivo, motiva un efecto de indefensión, que justifica por sí mismo el que 
se desencadene con todas sus consecuencias una iniciativa tuteladora por parte de las ciudades para garantizar la salvaguarda de sus derechos, cuya conservación se considera conveniente para el pro e bien del reino y, por tanto, para la conservación del patrimonio real.

Mientras que en otras cartas de hermandad se señala la idea de la avenencia entre concejos como movilizadora de la hermandad (nota 16), este otro concepto de la tutela vinculada a un contexto de indefensión por ausencia de gobierno regio efectivo, al que se acaba de aludir, presenta una notable perduración ya entrado el siglo XIV, lo que queda patente tanto por la vía de la intervención de los concejos en Cortes, tal como se comprueba en las de Burgos de 1315 (nota 17), como en nuevas cartas de hermandad más tardías, de manera que, en definitiva, los concejos actúan como albaceas de los derechos reales cuando éstos no pueden ser plenamente reivindicados por el monarca en un contexto de minoría de edad, tal como fue el caso de la correspondiente a Alfonso XI (nota 18).

Todo ello apuntaría, en definitiva, a una reivindicación concejil de un vínculo particular entre rey y concejos que legitimaría a éstos en el ejercicio de funciones políticas extraordinarias de salvaguarda del reino ante situaciones de alteración política 
Fragmentos de ideología política urbana en la castilla bajomedieval

excepcional. Acaso forme parte de ese mismo vínculo particular rey-ciudades, el que se pudiera poner de manifiesto la creencia de rasgos exageradamente providencialistas por la que se percibía alguna forma de conexión entre la prematura muerte de Fernando IV y los pecados de los súbditos (nota 19).

Si esto es lo que sucede durante época de minorías, la justificación de la resistencia a determinadas medidas reales en contextos de plenitud de funciones del monarca pasa por asociar lo conveniente al rey con lo que se entiende desde la ciudad como conveniente para ella. Así, no faltará el concejo que, aparte de alegar derechos tradicionales, se resista a determinadas medidas regias por cuanto provendrá de ellas «a esta villa gran danno», lo que tiene la consecuencia inevitable, en la perspectiva concejil, de provocar «al rey deseruiçio» (nota 20).

\section{La potenciación del gesto en el discurso político urbano (ca. 1350-1420)}

No siendo objeto de este trabajo la consideración de las expresiones ceremoniales y de las prácticas gestuales, no dejaría de tener un cierto efecto de deformación el no tener en cuenta que en el transcurso de la segunda mitad del siglo $\mathrm{XIV}$ y los comienzos del siglo $\mathrm{XV}$, consolidándose tal rasgo 
a lo largo del resto de esta centuria, pareció tener lugar una progresiva tendencia a la expresión gestual y objetual de los ideales políticos urbanos, de tal modo que si, como ya señalé en otro lugar, refiriéndome a la realeza (nota 21), tuvo lugar a lo largo de dicho periodo una presencia cada vez más notable de la ceremonia de significado político, otro tanto sucede para las ceremonias cuyo protagonista esencial es la propia ciudad, tratándose, sin duda, de una característica ampliamente extendida en todo el ámbito occidental (nota 22).

La solemnidad, por ejemplo, de actos típicamente urbanos como el juramento y pleito-homenaje de la ciudad de Toledo de guardar y cumplir el testamento del rey Pedro I en 1359 (nota 23), puede considerare como todo un anuncio de la nueva dimensión que iban a tomar los pleitos-homenajes y juramentos de los representantes de las ciudades con respecto al rey (nota 24), en particular, y la amplia conmemoración ceremonial con respecto a acontecimientos políticos significativos en general. El aludir ahora a tal cuestión, más que para entrar de lleno en ella, que tal como se decía, no es lo que se pretende, importa, sobre todo, para valorarlo como un factor de relativización de las expresiones ideológicas escritas aquí consideradas, puesto que, en definitiva, ahora estamos ante la ampliación de un recurso paralelo de comu- 


\section{Fragmentos de ideología política urbana en la castilla bajomedieval}

nicación de horizontes ideológicos, no faltando los momentos de complementación manifiesta de uno y otro, en los que la gestualidad se reforzaba con la literalidad de textos que ofrecían la oportunidad de incorporar un importante conjunto de expresiones de valor político destinadas a establecer derechos y deberes de apariencia objetiva como fundamento de los vínculos que se pretendían asentar por la mediación del rito (nota 25).

La multiplicación de celebraciones políticas urbanas realizadas muchas veces de cara a la propia ciudad con amplio despliegue ritual, no en función de la presencia de un poder externo, como sucedía con motivo de la llegada del rey y de las consiguientes entradas reales, sino de cara a la formalización de imágenes de uso interno, fue una práctica que debió de tener no poco relieve a la hora de favorecer esa toma de conciencia de la ciudad como comunidad política en sí misma, estructurada y organizada para la defensa de ideales que se suponían comunes, favoreciendo, a través de esa imagen integradora, un efecto de ocultamiento de las tensiones internas cotidianas (nota 26).

La referencia a la Corona pasa a tener ahora un protagonismo en el discurso ideológico urbano del que antes carecía, se trataba, en definitiva de un concepto que remitía a un objeto de 
relevante valor gestual, con respecto al cual se definían significaciones no exentas de implicaciones a la hora de definir el papel de las ciudades en el sistema político, en particular, con respecto al poder real. Ahora la corona se alzaba como una especie de entidad titular que ejercía dominio eminente sobre el conjunto del patrimonio real del que se sentían parte las ciudades realengas, redefiniendo al respecto la posición del monarca, al que se identifica más como un administrador que como un propietario de derechos (nota 27). Con ello tenía lugar en efecto de transpersonalización, en lo que se refería a la relación entre el rey y los derechos reales (nota 28).

Habrá de ser precisamente en este contexto de potenciación del gesto, del rito y de la ceremonia como instrumentos de expresión de discursos ideologizados protagonizados por las ciudades, en el que se demande la sistematización de las audiencias públicas de los monarcas. Así lo pedirán los procuradores de las ciudades a Pedro I en 1351 (nota 29), sin que falten peticiones de la misma índole ya en tiempos de los reyes trastámaras. Con ello, en definitiva, las ciudades trataban de traducir en un gesto preciso y constatable una imagen del rey como servidor de la comunidad y garante del buen gobierno mediante la percepción visual de la ejecución de la justicia (nota 30 ). 
Fragmentos de ideología política urbana en la castilla bajomedieval

\section{El absolutismo regio como polarizador del discurso urbano (1420-1454)}

El comienzo de la mayoría de edad de Juan II fue contemplado desde las ciudades como momento idóneo, tal como ha sido bien observado por algún autor (nota 31), para tomar las iniciativas necesarias a fin de actuar en tres frentes del mayor interés, desde el punto de vista de las aspiraciones políticas urbanas: conseguir mayor peso de las ciudades en el conjunto de la sociedad política, obtener una presencia más significativa en los órganos principales de gobierno y ampliar la influencia de las Cortes, contribuyendo a su mayor protagonismo en el marco de lo que parecía avecinarse como una época de reformas y transformaciones en la organización del poder real. Estos tres frentes, por tanto, definieron un complejo panorama de dilatada negociación entre ciudades y monarquía cuyo resultado estuvo bien lejos de suponer, en realidad, a pesar de aparentes concesiones, en muchos casos incumplidas en la práctica, resultados significativos acordes con las pretensiones urbanas (nota 32 ).

Tales circunstancias hacen que sean precisamente las Cortes el medio en el que acaso mejor se expresa durante este periodo, que lleva hasta avanzado el reinado de Enrique IV, los conceptos políticos manejados desde la ideología urbana, de 
manera que, a través de sus ordenamientos, a la vez que se puede percibir el conjunto de aspiraciones a las que se acaba de hacer referencia, también es posible observar cómo, ante el impulso alcanzado por las aspiraciones de desligamiento del rey con respecto a la ley y la ampliación de los rasgos absolutistas que iba tomando el poder real, los concejos fueron aceptando una cierta posición de complicidad con tal transformación, dudando entre entenderla como un mal menor o como un instrumento útil en el marco de otras amenazas, no poco preocupantes para los intereses concejiles, tal como la que representaban los poderes señoriales.

Seguramente muy relacionado con el papel que se concedió a las Cortes como ámbito privilegiado de argumentación ideológica y de negociación política fue el hecho de que en las mismas se dejase planteada con rotundidad la concepción de un reino organizado en tres estados (nota 33), con lo que parecía ofrecerse una oportunidad, que no siempre fue efectiva, a la afirmación y al reconocimiento institucional, sobre todo por parte de la monarquía, de que los intereses de las ciudades nunca, o tan sólo excepcionalmente, podían verse satisfechos con las concesiones recibidas por los estamentos privilegiados, pudiendo entrar éstas en colisión directa con dichos intereses. De este modo, este recurso a la figura de 


\section{Fragmentos de ideología política urbana en la castilla bajomedieval}

las ciudades como estado del reino, fundamentaba lo que parecía suponer la pretensión de configurar un discurso político propio.

Sin embargo, pronto pudieron comprobar las ciudades, tanto en la práctica política y administrativa cotidiana, como en el propio marco de las reuniones de Cortes, que sus esperanzas en el comienzo de la mayoría de edad de Juan II chocaban con un muro que parecía alzarse infranqueable y que venía, desde la perspectiva de sus intereses, sobre todo representado por el progresivo desligamiento del rey con respecto a la ley, lo que iría plasmándose de forma cada vez más reiterativa, aunque ciertamente no innovadora, en las cláusulas absolutorias derogatorias manejadas desde la monarquía para justificar las decisiones tomadas en contra de los ordenamientos legales vigentes.

Así se iniciaba un largo camino en el que la práctica de las Cortes se alejó cada vez más de cualquier forma de aplicación del principio de «quod omnes tangit, omnes debet aprobari», consolidándose, por el contrario, el criterio de la presencia de los procuradores de la ciudades en Cortes como resultado de un deber de consejo, más que de un derecho de representación (nota 34 ), lo que no impidió que los procuradores reivindicasen para sí esa dimensión represen- 
tativa (nota 35), mostrándose de este modo insensibles o, al menos poco activos para reaccionar a la contra respecto del proceso de evidente tendencia de control de las Cortes desde la Corte (nota 36).

Frente a la máxima recién aludida, "quod omnes...», muy pronto los concejos pudieron percibir indicios suficientes de que desde la monarquía se apostaba por una opción bien distinta, aquélla que venía a señalar que «princeps legibus solutus est» (nota 37). En efecto, el recurso regio a las cláusulas derogatorias, simbolizadas preferentemente en la alusión al "poderío real absoluto», tendió a convertirse de práctica excepcional en recurso casi ordinario. A la vez, desde muy pronto, mediante la expedición de pragmáticas, el rey puso de manifiesto que no tenía ningún empacho en producir leyes basadas en su propio criterio, sin consulta en Cortes, pero dándoles tanto vigor «como si hubieran sido aprobadas en Cortes».

Todas éstas fueron circunstancias y tendencias evolutivas en el proceso de transformación y caracterización del poder real que promovieron respuestas concretas en las formulaciones ideológicas expresadas desde los poderes urbanos. El rechazo de los concejos al uso de las cláusulas derogatorias por vía de alusión al poder absoluto del monarca fue objeto 


\section{Fragmentos de ideología política urbana en la castilla bajomedieval}

de reiterada manifestación por parte de los procuradores de las ciudades. Del mismo modo que la acción legisladora del monarca en contra de lo previamente legislado o de lo acordado en Cortes se resolvió en la apariencia de la formalidad administrativa, aunque no en la realidad política concreta, por la puesta en juego de la fórmula «obedézcase pero no se cumpla».

Dentro de estas reacciones ante las manifestaciones de índole absolutista del poder real hubo expresiones, como la petición 11 de las Cortes de Valladolid de 1442, comentada por distintos autores (nota 38 ), en la que los procuradores mostraron con precisión su posición y pretensiones respecto de los recursos empleados por la monarquía en su manifiesta tendencia a desligarse de la observancia de leyes preexistentes. Así ponen de relieve cómo desde la monarquía: «se ponen muchas exorbitançias de derecho enlas quales se dize non obstantes leyes e ordenamientos e otros derechos, que se cunpla e faga lo que vuestra sennoria manda e quelo manda de çierta sçiencia e sabiduria e poderio rreal absoluto e que rreuoca e cassa e anulla las dichas leyes que contra aquello fazen o fazer pueden, por lo qual non aprouechan avuestra merçet», pidiendo al rey, en consecuencia, "quelas tales cartas non sean conplidas e sean ningunas e de ningunt 
valor» (nota 39). El rey ofrecerá una respuesta de lo más cautelosa, remontándose a las Cortes de Briviesca y aceptando, al menos aparentemente, la exigencia de renuncia a las denominadas "cláusulas exorbitantes» y, por tanto, al uso del "poderío real absoluto». Sin embargo, lo que podría entenderse como una renuncia de valor general, tal como parece deducirse de la primera parte de la respuesta, queda a continuación reducido en su aplicación, al puntualizarse que tal renuncia sólo se produce con respecto a las «cartas que fueren entre partes o sobre negoçios de personas priuadas» (nota 40). En consecuencia, quedaba con ello perfectamente legalizado el uso del "poderío real absoluto» para todo lo demás y, muy en particular, para aquello que va a ser su ámbito característico de aplicación: la gracia y la merced, que tan directamente afectaban a la política municipal.

Fueron éstas las manifestaciones principales de la resistencia de las ciudades a aceptar el progresivo avance de la monarquía hacia soluciones absolutistas en la práctica de su participación en la gobernación del reino. Sin embargo, no dejó de producirse manifestaciones de una cierta actitud acomodaticia de las ciudades hacia estas prácticas, de modo que a la vista de determinadas expresiones, se tiene la sensación de que entraron en el juego de una concepción de las 


\section{Fragmentos de ideología política urbana en la castilla}

bajomedieval

relaciones con el rey asentadas sobre un modelo de gobierno por la gracia al que era necesario adaptarse (nota 41), incorporando al propio discurso ideológico urbano y a sus formas de representación, cuando se trataba de relacionarse con la monarquía, referentes ideológicos y administrativos coherentes con tal forma política.

Por de pronto, los propios textos de Cortes ponen de manifiesto cómo el recurso a la súplica se erige en el instrumento más característico utilizado por los procuradores en Cortes para presentar sus demandas ante el rey (nota 42). Bien podría decirse que se pasa de la tradicional petición en Cortes a la súplica, con todo lo que esta última implicaba de legitimación de una práctica de gobierno por la gracia, potenciando así los procuradores, en el plano de lo retórico la inclusión de las demandas de las ciudades en el terreno de la gracia real.

Del mismo modo, los procuradores de las ciudades incorporaron a su propio discurso político la evidente tendencia teologizadora que desde la monarquía se asociaba como factor coadyuvante a su proyecto de progresiva desvinculación con respecto a la observancia de las leyes. Así, en las Cortes de Valladolid de 1440, se hace al comienzo de la reunión una declaración por parte de los procuradores de las ciudades 
en donde el criterio teologizador, desde el que se enfoca el oficio regio, deja abiertos evidentes resquicios a una posible interpretación absolutista del poder regio (nota 43). Así, partiéndose de la condición del rey como quien tiene el lugar de Dios en la tierra y es soberano señor, se establece que, por mandato divino, debe buscar todas las vías posibles para alcanzar la concordia y la paz. Ningún límite se apunta en cuanto a estas posibles vías, siendo factible el que se pueda pensar en ir más allá de lo que el Derecho y las leyes permiten, teniendo en cuenta la definición teocéntrica que se ha dado del monarca y la prioridad de los objetivos que se pretenden. Esta misma línea de supremacía del rey sobre la ley y su justificación a partir de criterios de teología política que, de hecho, convertían en persona incuestionable al rex inutilis fue la que alcanzó el pleno respaldo de los procuradores reunidos en el real de Olmedo en 1445 (nota 44), si bien, no dejaba de ser un respaldo a las opciones absolutistas máximas de la realeza que se concedía en un contexto de máxima excepcionalidad política, como consecuencia del conflicto en curso de Juan II con los infantes de Aragón. En cualquier caso, da indicio de hasta qué punto las décadas de resistencia al absolutismo real de los representantes de las ciudades parecían haber desembocado en un evidente entreguismo de 


\section{Fragmentos de ideología política urbana en la castilla bajomedieval}

éstos a las opciones más favorables a los proyectos monárquicos sostenidos por su privado don Álvaro de Luna.

En las primeras reuniones que siguieron a las Cortes de Olmedo de 1445, el discurso ideológico de los representantes de las ciudades incidiría en la idea de que cuanto más poderoso fuera el rey, mejor sería la situación e las ciudades, lo que parecía una toma de postura con respecto a la inestabilidad de las relaciones entre parte de la alta nobleza y la monarquía (nota 45). Ello no supuso, sin embargo, la entera desaparición de los resquemores urbanos hacia las reiteradas manifestaciones de desligamiento del rey hacia la ley, produciéndose intervenciones de los procuradores contra lo que consideraban excesos del poder regio, así, por ejemplo, al conceder, a petición de parte, el sobreseimiento o la revocación de actuaciones judiciales por la libre iniciativa del rey, sin contar con el Consejo, y por la sola aplicación de las denominadas "cláusulas exorbitantes» vinculadas al ejercicio del poder absoluto del monarca (nota 46), lo que ponía de relieve que, tal dimensión del poder regio estaba lejos de ser enteramente asumida por la mentalidad política urbana.

En la trayectoria de estos años no dejó de haber momentos excepcionales cuyas circunstancias políticas motivaron también esfuerzos excepcionales a la hora de estructurar en el 
medio urbano discursos de ideología política coherentes con los conflictos en curso. Ocasión muy relevante de tal índole fue la que se planteó con motivo de los conflictos acaecidos en la ciudad de Toledo entre 1448 y 1449 con ocasión de las tensiones surgidas con relación al problema converso.

Probablemente siga siendo el análisis del prof. Gutiérrez Nieto uno de los más acertados respecto de algunos de los rasgos más significativos de relieve ideológico exhibidos en la retórica desplegada para la ocasión del bachiller Marcos García de Mora, como intérprete prominente de aquel movimiento urbano. El mencionado autor puso de relieve cómo el memorial del citado bachiller, principal teorizador de la rebelión toledana, se asentaba sobre cuatro principios básicos (nota 47):

- Las disposiciones emanadas del poder público supremo que son contrarias a derecho o a la utilidad pública carecen de validez preceptiva.

- Cuando el príncipe no quiere administrar justicia o la administra arbitrariamente o dicta disposiciones contrarias a derechos permanentes del súbdito, como es el respeto a sus bienes o a su libertad o atenta contra el bien comunitario, se da el estado denominado de defecto de jurisdicción, 


\section{Fragmentos de ideología política urbana en la castilla bajomedieval}

ante el cual cabe el derecho de resistencia, el derecho de defensión.

- En el caso de tiranía, el gestor del poder público pierde la administración, que debe pasar a su sucesor, o en su defecto, a las ciudades.

- La resistencia a las disposiciones reales injustas es, además de un derecho, una obligación.

De acuerdo con estos criterios, se daba fundamento a lo que, según los criterios de los sublevados, se podía considerar como una rebelión legítima, pudiéndose resistir así la ciudad frente al monarca "con todos los remedios defensorios que por mengua de justicia les compete o competer puede de hecho e de derecho».

Sin embargo, si en todo lo recién señalado se recoge lo que, en definitiva, suponía el fundamento de legitimidad de la rebelión toledana, en el marco de un conflicto fuertemente ideologizado, a lo largo del memorial del citado bachiller abundaban consideraciones de no poco interés a la hora de definir lo que era un ideario político planteado desde la perspectiva de una ciudad que se oponía al rey. Por de pronto, no debe pasar desapercibido el hecho de que se aluda a la ciudad de Toledo como santa de manera reiterada, lo que parecía fun- 
damentar un estatus de inviolabilidad para la misma, dotando de los rasgos del acto herético cualquier intento de torcer la voluntad de sus habitantes, constituyendo al mismo Dios en su valedor (nota 48 ).

El propio concepto de defecto de jurisdicción antes aludido se argumenta con referencias ideológicas de un contenido teológico más profundo del que solía ser común en las argumentaciones políticas de origen urbano, pues, tras afirmar que «los Príncipes que son negligentes en la execuçion de la justicia, si su negligencia es grande o universal, o si trata cruelmente a sus súbditos e naturales, si defiende a los hereges e siendo requerido continua en la tal negligencia o crueldad o discensión, pierdan la administración de los Principados, Reynos e señoríos», aplica tales consideraciones al caso toledano, al señalar que "la dicha ciudad de Toledo requirió en forma de derecho solemne e públicamente al dicho señor Rey que los oyese a justicia e a derecho en lugar seguro e ante personas sin sospecha e no lo quiso facer, e por esto la dicha ciudad le constringió la obediencia e appeló dél e se puso so amparo de Dios e de aquél o aquéllos a quien pertenecía proueer o conocer de semejantes echos, por lo qual todos quantos autos e procesos hauía echo e face e fará contra la dicha ciudad e vecinos e valedores della son 


\section{Fragmentos de ideología política urbana en la castilla bajomedieval}

e serán ningunos ipso jure por defecto de juridiçión, e los tales naturales de sus Reynos no son obligados a cumplir sus mandamientos» (nota 49). El recurso a argumentos de orden teológico en sus expresiones más terminantes, se unen a la justificación política de las iniciativas de la ciudad al afirmar que «la ciudad no erró ni delinquió en hacer lo que hiço acerca de lo suso dicho, antes hiço gran seruiçio a Dios y al dicho señor Rey si lo quisiere conocer, e gran prouecho a la república de los dichos Reynos, especialmente de la dicha ciudad (...) mas fue fecho por mandado del Espíritu Santo que no por misterio ni fuerças comparables y el Santo Espíritu no es sujeto a las leyes ni a redempción ni raçon humana, ca ninguna saue de dónde viene ni dónde va» (nota 50). A partir de varios juristas, entre los que cita a Baldo, reivindica la resistencia frente al rey, considerando que «los súbditos de los dichos Reyes no cumplan los mandamientos injustos, porque aunque ellos quieran errar, manda la dicha ley que no se lo consientan sus súbditos» (nota 51), lo que le lleva a sostener que la rebelión de la ciudad de Toledo no fue tal, no siendo rebelión, sino defensión. Además toma postura claramente opuesta, como no podía ser de otro modo, en coherencia con lo ya señalado, con respecto al poder real absoluto: «mienten como proditores linsonjeros, destruidores y como aquéllos que con linsojas, falsedades y mentiras hazen errar a su Rey 
y le hazen entender que puede usar de poderío absoluto» (nota 52).

En fin, este variado conjunto de argumentos que se podrían sumar a otros muchos que van desgranándose a lo largo del citado memorial nos pone sobre aviso de que, hacia mediados del siglo XV, a la vez que se ha producido un evidente enriquecimiento de las referencias argumentativas desde las que se podía pensar sobre el lugar político que le correspondía a la ciudad en el conjunto del reino, la evolución de los acontecimientos parece abocar a una significativa diversidad de opciones ideológicas que habrán de coexistir durante largo tiempo, lo que no impedirá el predominio de unas sobre otras desde el punto de vista de sus posibilidades de aplicación política concretas.

\section{La coexistencia de discursos urbanos alternativos (1454-1474)}

Las tensiones políticas que caracterizaron el reinado de Enrique IV supusieron, desde el punto de vista de la evolución de la ideología política urbana, una especie de oportunidad de expresar aspiraciones y creencias que parecían haber estado ocultadas por la presión de la ideología política dominante vinculada a la expansión de las pretensiones absolutistas de 


\section{Fragmentos de ideología política urbana en la castilla bajomedieval}

la monarquía. El resultado inevitable de esto fue la tendencia a la coexistencia de discursos urbanos de sentido diverso.

En los comienzos del reinado, tal como se reflejó en las primeras reuniones de Cortes, las manifestaciones de los procuradores se mantuvieron bajo una evidente línea de continuidad con respecto a lo que habían significado las simbólicas Cortes de 1445, en las que se había formalizado la adhesión de los representantes de las ciudades a los planteamientos absolutistas auspiciados por don Álvaro de Luna.

En efecto, tanto en las Cortes de Córdoba de 1455 (nota 53), como en las de Toledo de 1462 (nota 54), los procuradores comenzarían la relación de sus peticiones con una declaración de principios perfectamente en consonancia con el espíritu de las Cortes de Olmedo de 1445, es decir, reconociendo el origen divino del poder real y sacando de ello la consecuencia inmediata de la incontestabilidad de su preeminencia, de su posición como juez supremo y de su libre capacidad para dar leyes y ordenamientos, lo que parece indicar que el mensaje de aquellas Cortes de Olmedo que podían parecer en algunos puntos fuera de la realidad en su afán de recuperar los contenidos más autoritarios del pensamiento político alfonsino reflejado en la segunda de las Partidas, ha- 
bía calado en el medio urbano más de lo que hubiera cabido esperar entonces.

Tanto en las Cortes de 1455, como en las de 1462, el discurso inicial pronunciado por el representante de las ciudades se mueve en torno a tres claves. La primera de ellas se refiere al carácter del reino como encomendación de origen divino a favor del rey, convirtiendo el vicariato divino en fundamento esencial de los derechos y deberes del monarca hacia sus ciudades: "el rrey es tenydo de guardar e mantener entre todas las otras cosas que Dios le encomendó por el estado e lugar que del ha en la tierra». En segundo lugar se apela a la concepción corporativa: "por que quiso (Dios) que fuese príncipe e cabeça de su rreyno, e ansy commo por la cabeça se rrigen e gobiernan todos los myenbros corporales ansy el rrey debe con gran diligencia e pensamiento buscar manera por do sus pueblos sean rregidos en paz». Por último, se pone de relieve la función legisladora del monarca, que se acepta como de institución divina, como medio esencial de administrar y pacificar el reino: "por eso estableció Dios el poderio del príncipe que rremedie alas cosas graves con claros entendimientos e las mal hordenadas mejore e rremedie a pro e bien de sus subditos, e las cosas nuevas determyne con leyes e ordenamyentos» (nota 55). 


\section{Fragmentos de ideología política urbana en la castilla bajomedieval}

Ciertamente, no faltaron en estas mismas reuniones de Cortes las denuncias de los procuradores de las ciudades contra los excesos reales en la expedición de ciertas cartas (nota 56), para las que se exige que se les aplique la fórmula "obedézcase, pero no se cumpla» (nota 57), o contra los abusos en el recurso al "poderío real absoluto» (nota 58), o los excesos en la aplicación de la gracia real en su manifestación a través de las cartas de perdón (nota 59).

En cualquier caso, las expresiones de índole ideológica antes señaladas permiten comprender que la actitud de sujeción de las ciudades al poder real permitiera que las ciudades aceptasen el que el monarca se apropiase de iniciativas tradicionalmente tan propias de aquéllas como la organización de hermandades concejiles, que ahora se planteaban como un claro instrumento al servicio del poder real y no como una forma de organización autónoma de las ciudades para ejercer mayor peso político en el reino (nota 60). Con ello parecía evidenciarse la convicción o, al menos, la apariencia de convicción de que, en aquellos momentos, el rey era el representante genuino del bien común de las ciudades y del reino.

Sin embargo, a poco de iniciarse el reinado, llama la atención cómo comienzan a surgir indicios que evidencian la presen- 
cia de referentes ideológicos que bien podían contribuir a la fundamentación de alternativas ideológicas susceptibles de justificar el desligamiento de las ciudades con respecto a la adhesión que venían mostrando respecto a la opción ideológica favorecida desde los intereses reales. Así llama la atención que se reivindique en un documento de 1458 como ideal político el sacrificio individual hasta la muerte por defender la ciudad y, en concreto, «la cosa pública de su ciudad e libertad de ella». Bien es verdad, no obstante, que esta exigencia se situaba sólo en tercer lugar, estando precedida por el deber de dar la vida, primero por la ley, y, en segundo lugar, por el rey (nota 61). A la vez, por aquel mismo año, se aludía en otro texto a la dicotomía entre el servicio al rey y el servicio a la ciudad. Aunque lo cierto es que tal dicotomía se planteaba en una situación en la que se ponía de relieve la plena compatibilidad entre ambos servicios (nota 62). En cualquier caso, podía entenderse que se dejaba la puerta abierta a que pudieran acabar dándose, tal como sucedió en un plazo no muy largo, unas circunstancias de incompatibilidad, debiendo entonces de elegir entre una opción de servicio u otra.

En el mismo documento se aludía al concepto de «bien vivir», que se planteaba en términos puramente localistas y 


\section{Fragmentos de ideología política urbana en la castilla bajomedieval}

que parecía enfocarse desde perspectivas más inmediatas y pragmáticas que las que solían reflejarses en la tradicional referencia al pro e bien común del reino, lo que podía introducir otro factor ideológico de diferenciación entre intereses del rey y del reino e intereses locales de una ciudad concreta.

Si todos ellos podían considerarse tan sólo como indicios de ciertos cambios en la ideología política urbana, el conflicto armado entre 1465 y 1468 supondría el contexto que favorecería el impulso de esta diferenciación ideológica entre la formula autoritario-absolutista que parecían haber asumido como mal menor as ciudades desde fines del reinado de Juan II y otra de tintes más populistas.

La vuelta a la hermandad concejil como instrumento de defensa de los intereses políticos en un reino en conflicto tornó a convertirse, como a fines del siglo XIII y comienzos del siglo XIV, en la expresión organizada de los nuevos referentes ideológicos desde los que se contemplaban los conflictos en curso que se acompañaban de otros referentes ideológicos más añejos.

Mediante las ordenanzas dadas en la villa de Castronuño se definieron los objetivos y organización de la denominada Santa Hermandad de los Reinos de Castilla y León (nota 63). Algunas de las principales expresiones de la dimensión ideo- 
lógica de tal iniciativa se plasman en algunos de los contenidos de dichas ordenanzas. Ya resulta por sí mismo relevante el que se aluda a la denominación "Santa» para lo que era una organización civil. Convendrá recordar con relación a tal cuestión cómo con motivo de la revuelta toledana de 14481449 se hablaba por los sublevados de «santa ciudad de Toledo». Por otro lado, el propio impulso de la caracterización absolutista del poder real se había producido en estrecha asociación con una fuerte tendencia a la teologización del poder real, pudiendo pensarse que tal proceso de teologización también pudo extenderse a una interpretación más genérica de las iniciativas políticas, no sólo las protagonizadas directamente por la realeza. También en este sentido la revuelta toledana antes aludida, tal como se puso entonces de relieve, puede representar un claro ejemplo de tal tendencia. Además, en el contexto del conflicto iniciado en 1464-1465, parecía que todas las opciones en juego, desde la real, hasta la antienriqueña, debían dotarse de referentes teologizadores a fin de ampliar su base de legitimidad, lo que explica la persistente apelación al pontificado por parte de ambos bandos para reclamar su respaldo (nota 64). Por todo ello, este apelativo de "santa» adquiriría particular coherencia y significado, que se vendría a reforzar si tenemos en cuenta que la última de las decisiones que se incorpora a estas or- 


\section{Fragmentos de ideología política urbana en la castilla bajomedieval}

denanzas impone que se realice una procesión en cada una de las villas y ciudades hermanadas «por que a Dios Nuestro Señor plega conseruar e aumentar esta Sancta hermandat» (nota 65).

No obstante, la principal fundamentación ideológica de esta santa hermandad concejil se precisa en el capítulo IX de estas ordenanzas, cuando se afirma que «les plega, como naturales, dolerse del dapno e destruymyento destos Regnos e de la Corona Real dellos, e myrar cómo sy non se remedya e se ponen todas fuerças por todos los tres estados, que todo el Regno es destruydo, e apartado e enaxenado de la Corona Real e la iustiçia perdida» (nota 66). Se trataba este fragmento, en realidad, de un mensaje que iba dirigido a los habitantes privilegiados de las ciudades $y$, en particular, a clérigos, caballeros y escuderos. Pero su valoración, desde el punto de vista del transfondo ideológico del movimiento, debe ser necesariamente más amplia. En él, en definitiva, se estaba invocando el viejo derecho de defensión y de resistencia, referentes inspiradores de la mayor parte de las iniciativas de hermandad urbana, que se valoraba ahora como deber del natural con respecto a su reino y corona real, de modo que, una vez más, como ya se advirtiese en ocasiones 
anteriores, la corona se convertía en sujeto de derechos específicos, diferenciándose de la propia persona real.

Derecho de resistencia y de defensa se alzaban ahora, no sólo como tales derechos, sino también como deberes característicos de los naturales del reino, como unos deberes hacia la corona real, no tanto hacia el rey, ante la ausencia de función gubernativa efectiva y de ausencia de justicia. La esencia de tal argumentación era la que iba a estar en la base de todas las iniciativas que supusieran alguna forma de resistencia a los mandatos reales hasta la epoca de las Comunidades (nota 67).

Junto a estas ordenanzas que Castronuño, que han sido las tradicionalmente empleadas casi en exclusiva hasta hace pocos años para aproximarse a la caracterización de estas hermandades, el descubrimiento de otros cuadernos referentes a los años 1466 y 1467 ha permitido ampliar el análisis de sus fundamentos ideológicos (nota 68). En estos otros textos se abundaba en algunos de los móviles ideológicos ya apuntados, tales como eran, sobre todo, los referentes a la preocupación por la enajenación del patrimonio real y por la disminución de la justicia en detrimento del cumplimiento de las leyes (nota 69). Por lo que se refiere al rey, si bien, según un informe remitido al rey, referido a la reunión de la herman- 


\section{Fragmentos de ideología política urbana en la castilla bajomedieval}

dad en Fuensalida se presenta tal iniciativa como "cosa que mucho cumple a vuestro servicio e en que muy grand favor recibe vuestro estado real e todos enderescan a la justicia que es todo el cabdal de vuestra real señoría», lo cierto es que las alusiones a la monarquía se producen en clave de expresiones como la que acaba de reseñarse, "estado real», o bien la característica referencia a la "corona real», evitando, lo que ya podía ser sintomático, la vinculación directa entre hermandad y persona del rey (nota 70), pareciendo buscarse, tal como ha sido tan frecuente en los pronunciamientos de las ciudades, una medida distancia que permitiera evidenciar una impersonalización del movimiento concejil que se mostraba actuando en función de conceptos objetivos de valor general para la comunidad política y, por tanto, manifestándose así ajeno a cualquier forma de dependencia con respecto a los monarcas.

Las Cortes de Ocaña de 1469 supusieron la ocasión de los procuradores de las ciudades para pasar factura al monarca por el apoyo que, aunque no declarado, en la práctica se le había prestado desde la hermandad, al abrirse un tercer frene que debilitaba más a los nobles sublevados a que a los partidarios de Enrique IV, reflejándose precisamente en estas Cortes algunos de los criterios que habían presidido el 
recurso a la hermandad de ciudades en los años anteriores como forma de defensa de los intereses concejiles (nota 71). Fue seguramente por esto que la voz de estos procuradores parece expresarse con una libertad de criterio que no parece detectarse en Cortes anteriores desde, al menos, los años cuarenta, planteando ahora criterios de caracterización del poder real y de sus relaciones con las ciudades y los naturales del reino que tenían mucho de contrapuesto con lo que ellos mismos habían aprobado en las Cortes de Olmedo de 1445. Puntos esenciales de sus planteamientos ideológicos eran los siguientes (nota 72):

1) «El ofiçio del rrey asy por su primera ynvençion commo por su nonbre es rregir, $y$ ha se de entender, bien rregir, por que el rrey que mal rrige no rrige, mas disipa». Lo que resultaba incompatible con cualquier idea de incontestabilidad del poder regio, que quedaba ahora legítimamente sometido a la crítica de los procuradores de las ciudades.

2) «Propio es a los reyes hazer juyzio e justiçia e por el exerçiçio de aquesta prometió Dios por boca de su propheta alos rreyes, perpetuydad de su poder». En consecuencia, si no se discutía el origen divino del poder regio, tal origen divino imponía un carácter finalista a la función regia, la de mantener al reino en justicia, no cumpliendo 
Fragmentos de ideología política urbana en la castilla bajomedieval

tal fin, el origen divino no legitimaba por sí sólo el ejercicio de un poder otorgado para cumplir un objetivo concreto.

3) «E vuestro cargo es que mientra vuestros subditos duermen vuestra alteza vele guardando los, y su meresçenario soys pues soldada desto vos dan vuestros subditos parte de sus frutos e de las ganançias de su yndustria, y vos siruen con sus personas muy ahincada mente alos tienpos de vuestras nescesidades por vos hacer mas poderoso para que rreleuedes las suyas e quiteys sus vexaçiones». La función regia se concebía, por tanto, como servicio a la comunidad, que se reconocía legitimada para fiscalizar el grado de cumplimiento de tal función.

4) «Pues mire vuestra alteza si es obligado por contrato callado alos tener y mantener en justiçia e considere de quanta dignidad es çerca de Dios aquesta virtud deyfica». Las consideraciones establecidas en el punto anterior se precisaban aún más por medio de su caracterización como fórmula contractual entre el rey y los naturales del reino.

5) Por último, se hacían reiteradas alusiones al interés y compromiso de las ciudades, que se exigía en los mismos términos para el rey, con la defensa y protección del patrimonio real y de la corona: «en quanta diminuçión e menoscabo 
es venida la vuestra corona rreal (...) dapno e diminuçion de su corona rreal (...) hacer flaco vuestro çetro rreal (...) conseruar la potencia e union dela corona rreal (...)».

Tal como se puede ver, el programa político que dibujaban los procuradores reunidos en Ocaña no ponía en cuestión determinados principios monárquicos fundamentales, tales como podían ser el origen divino de la realeza o la idea de preeminencia real, pero sí que se oponía a cualquier pretensión de interpretación absolutista del poder regio. Su ejercicio se sometía a una especie de relación contractual, quedando, en definitiva, delimitado por el respeto a la ley y por los propios contenidos del "contrato callado» al que aludían los representantes de las ciudades.

Los efectos resultantes de estas Cortes fueron bien limitados (nota 73), suponiendo su celebración la oportunidad para los procuradores de las ciudades de expresar criterios de articulación política no dependientes de la estrecha vinculación que mantenían los propios procuradores con la corte real y más acordes con las inquietudes específicas de la mentalidad política característica en el momento en el medio urbano.

Las "cláusulas exorbitantes» no dejarían de formar parte de la redacción de determinado tipo de documentación real en los años finales de Enrique IV, lo que suponía actuar de es- 


\section{Fragmentos de ideología política urbana en la castilla bajomedieval}

paldas al programa de las Cortes de Ocaña, y la enajenación del patrimonio real y la cesión de atribuciones políticas a favor de determinados nobles constituía parte esencial de los acuerdos del monarca, realizados de espaldas a las Cortes, para pacificar a la alta nobleza, lo que abría una evidente contradicción entre el proyecto político de Ocaña y el devenir político inmediato (nota 74).

En cualquier caso, en Ocaña se había patentizado un fenómeno de diversificación de la representación de lo político desde la perspectiva urbana, de modo que, en el transcurso de unas pocas décadas, había pasado por actitudes que iban desde acomodarse a los enunciados más absolutistas, hasta la justificación de la sublevación contra el rey tirano, o la recuperación de la fórmula del hermanamiento concejil en función de criterios ideológicos actuales que no rompían del todo con los de tiempo anteriores, hasta llegar, tal como se hizo en Ocaña, a la formulación de un modelo contractual de relación entre rey y ciudades (nota 75). Llegados a este punto en la evolución de la ideología política urbana, no era de extrañar que un típico representante del mundo urbano, un catedrático de la universidad de Salamanca, Fernando de Roa, hacia 1470 , reivindicase como modelo político la república de los medianos, aunque fuera pensando en las bondades el pen- 
samiento de Aristóteles que en la valoración concreta de los acontecimientos políticos recientes, exaltando así la función de las ciudades como articuladoras de un espacio político amplio y heterogéneo, tal como era el reino (nota 76).

Aún antes de concluir el reinado de Enrique IV se produciría un acontecimiento que muestra cómo, si el espíritu de Ocaña no estaba totalmente muerto, sí que se había rebajado considerablemente su horizonte reivindicativo. Así, en 1473, se promoverá la organización de otra Santa Hermandad ante la situación de desgobierno del reino (nota 77). Pero en este caso, si bien los concejos manifiestan que de mantenerse pasivo el rey procederían según «Dios les administrase», lo cierto es que someten su iniciativa a la confirmación regia y aseguran que, en cualquier caso, actuarían guardando el servicio del rey, con lo que parecía volverse a una de las claves del modelo de monarquía autoritaria que pasaba necesariamente por la identificación entre servicio al reino y servicio al rey.

\section{La ciudad como sujeto de mitificación}

Del mismo modo que hay fenómenos relacionados con las expresiones ideológicas concejiles que responden a cronologías precisas y a contextos concretos, tales como los que se acaban de considerar, hay otros que comienzan a dar indicios tímidos de presencia de manera aislada, para acabar 


\section{Fragmentos de ideología política urbana en la castilla bajomedieval}

convirtiéndose en expresiones reiteradas a lo largo de una cronología extensa, actuando como rasgos muy expresivos de una ideología conectada, en cualquier caso, con aspiraciones políticas evidentes.

Fue la caracterización de determinadas ciudades como «noble ciudad» o como "muy noble ciudad» una de las manifestaciones más evidentes y reiteradas de estas tendencias mitificadoras. Alfonso X ya se dirigía en 1255 a una ciudad castellana particularmente relevante como Burgos, aludiendo a ella como noble ciudad (nota 78), pareciendo plantearse en términos de excepcionalidad $y$, en definitiva, bajo voluntad de situarla en en posición eminente con respecto a todas las demás del reino. Teniendo en cuenta que la receptora de tal apelativo era, tal como se acaba de señalar, la ciudad de Burgos, también aludida por el mismo rey como «cabeza de Castilla», cabe pensar que el uso de tal título a favor de esta ciudad tuviera más interés para el propio monarca que para la ciudad en cuestión, puesto que en aquel año de 1255 Burgos se convirtió en una residencia particularmente frecuente para la Corte real, a la vez que se estaba en el comienzo del intento de expansión del Fuero Real (nota 79), que era visto con tantas reservas por los concejos castellanos, por lo que cualquier expediente que sirviera para congraciarse con 
los concejos más influyentes, como era el caso del burgalés (nota 80 ), podía constituir una alianza nada despreciable para los nuevos proyectos regios en materia de política concejil, tan dependientes, en el futuro, del éxito de la uniformación jurídica que se pretendía.

Sin embargo, lo que comenzó siendo una forma de distinción por iniciativa regia de una ciudad en un contexto de desarrollo de una política municipal abocada a ser contestada desde las ciudades, más tarde, ya en el transcurso de los siglos XIV y $\mathrm{XV}$, fue originando un mecanismo ideológico impulsado desde los propios concejos como era el de dar fundamento a un proceso de mitificación que pasaba por estrategias tan características como el ennoblecimiento de la ciudad, la apelación a un pasado más o menos fantástico, cuando menos exagerado, de privilegios y derechos locales omnímodos o, más adelante, la vinculación a la trayectoria de determinados héroes mitológicos o de hechos pseudohistóricos extraordinarios, junto con el impulso de toda una simbología individualizadora de cada ciudad, habiéndose puesto de relieve cómo las ciudades castellanas fueron adquiriendo a lo largo de la época bajomedieval plena conciencia de su carácter como «persona colectiva con identidad no sólo jurídica, sino también histórica y simbólica siempre en el marco común del reino» (nota 81). 


\section{Fragmentos de ideología política urbana en la castilla bajomedieval}

Por todo ello, no es de extrañar que se convierta en un recurso común en la negociación entre concejos y monarcas la apelación como referente legitimador a los privilegios y franquezas de los "reyes onde nos venimos», asegurándose larga vida al argumento para el conjunto de la época Trastámara, al quedar incorporado a la primera demanda colectiva de confirmación de privilegios concejiles que se reivindica con motivo de las primeras Cortes celebradas por Enrique II en 1367 (nota 82).

La ampliación del papel de la nobleza en la vida política del reino, así como la persistencia de las tensiones nobleza-monarquía y nobleza-ciudades, seguramente sería un factor que contribuiría a profundizar en esa dimensión del proceso mitificador urbano caracterizado por la reivindicación de nobleza para las principales ciudades del reino ya en el transcurso del siglo XV. En tal reivindicación, las ciudades no dejaron de tener un cierto éxito, si se tiene en cuenta la introducción de las referencias a los orígenes míticos de cada una en algunos de los nobiliarios más característicos del siglo XVI, planteando una correspondencia entre ciudades y tierras nobles y la criazón de muchos nobles en ellas (nota 83). Tal vez sea exagerado afirmar, a partir de este hecho, el que las ciudades desarrollarían una cierta forma de imaginario 
muy próximo al aristocrático (nota 84), lo que no obsta para pensar en circunstancias y móviles que, en alguna medida, podían contribuir a aproximarlos a ambos. En efecto, a tal proceso mitificador no debían ser ajenas pretensiones como las siguientes:

1. La pretensión de equipararse $o$, al menos, aproximarse en derechos políticos con la verdadera nobleza, no debiendo ser ajena a la misma la de índole fiscal.

2. La pretensión, asimismo, de las ciudades más importantes de jerarquizar por su mayor o menor condición nobiliaria a las distintas ciudades del reino, lo que no sería aspecto poco importante, si se tienen en cuenta las distintas confrontaciones entre ciudades castellanas con motivo de problemas de prelación (nota 85). Así se iría distinguiendo entre villas o ciudades «muy nobles», «nobles», o simplemente, carentes de tal estatuto.

3. Y, por último, la pretensión de convertir el ennoblecimiento de la ciudad en un factor de enaltecimiento que, en general, podía contribuir a consolidar su posición frente a cualquier otra instancia política.

El caso es que, tal como ha sido bien observado para la ciudad de Burgos (nota 86), el concepto de la honra de la villa 


\section{Fragmentos de ideología política urbana en la castilla}

bajomedieval

se adquiere en el transcurso del siglo XV como importante entidad como rasgo muy característico del discurso político urbano que le fue propio. Tal aspecto, naturalmente, era susceptible de rebasar el plano de lo ideológico, para introducirse en el de las tensiones político-sociales internas dentro de cada universo urbano concreto.

A partir del momento en que se reconocía la existencia de una honra propia de la ciudad, se enaltecía el relieve político y social de aquellos que actuaban como los guardianes, protectores y, en su caso, acrecentadores de esta honra, que no podían ser otros que los que acaparaban los principales cargos concejiles. De tal modo que la referencia a la honra de la ciudad no tenía por qué limitar su aplicación y posible eficacia a las relaciones exteriores, sino que también podía tener un uso político interesado en las relaciones en el marco del propio espacio urbano de una ciudad concreta, contribuyendo a resaltar la preeminencia política y social de los que, en definitiva, ostentaban la administración de esa honra.

\section{Conclusiones: un diálogo de exhibición y de ocultación}

A comienzos del reinado de los Reyes Católicos estaban abiertas variadas posibilidades de argumentación ideológica desde la perspectiva urbana, ofreciendo un amplio abanico 
de opciones que iban desde las que se hallaban más en consonancia con los principios absolutistas enunciados desde el entorno regio hasta aquellas otras que ponían especial énfasis en la titularidad de la ciudad de unos derechos de resistencia y de defensa frente a los abusos de otras instancias de poder y, en especial, ante la dejación de funciones gubernativas por parte de la monarquía. La propia evolución de dicho reinado, tanto política como ideológica (nota 87), contribuirá a debilitar esta última opción de perfil más populista, frente a los avances de los criterios absolutistas de que se iba rodeando el poder real, lo que no impediría que, desde los muy primeros años del siglo XVI, la argumentación ideológica contraria a estos últimos volviera a hacerse más patente en el medio urbano (nota 88).

De este modo, al término de la evolución bajomedieval, la diversidad ideológica, según los enunciados difundidos desde el medio urbano, se había convertido en uno de los rasgos más característicos de su discurso político. Al igual que había ocurrido con la ideología nobiliaria en el transcurso del siglo XV (nota 89), muchos de sus contenidos habían tomado uno u otro cariz por cuanto habían partido en su elaboración, además de lo que eran referencias comunes del pensamiento político occidental, del propio sentido que habían tomado las 
Fragmentos de ideología política urbana en la castilla bajomedieval

relaciones ciudades-monarquía al hilo de los acontecimientos concretos que habían originado una muy diversa casuística, bien diferenciada para una u otra ciudad, justificando significativamente la presencia de estos discursos políticos diversos.

Rasgo consustancial al discurso político urbano había sido su doble y alternativa funcionalidad contrapuesta de exhibición o de ocultación. Fue, por lo común en los momentos de mayor inestabilidad política global del reino, en muchos casos coincidiendo con minorías de edad del monarca o con crisis políticas específicas en la relación entre una ciudad y la monarquía cuando se hizo un tipo de exposición ideológica en la que se hacía un discurso de la exhibición, en el que se promovía la alusión reiterativa a derechos y atribuciones del poder urbano con relación a la gobernación general del reino, presentando a la ciudad como garantía última de los derechos de la corona y refugio de los defensores del bien común del reino, ofreciendo la impresión de que se trataba de enunciados destinados a reivindicar para la ciudad una posición más significativa en las relaciones políticas que articulaban la organización política del conjunto del reino.

Frente a este tipo de discurso de la exhibición, asociable a contextos de profunda crisis política, fue más común aquel 
tipo de discurso de la ocultación en el que sobre todo se exaltaba la idea de unidad interna de la ciudad como una realidad política armónica, pacífica y unánime. Se trataba de un tipo de discurso más destinado a lo que podría considerarse como el consumo interno de la propia ciudad emisora y que parecía predominantemente concebido para la ocultación de tensiones internas, ofreciendo una imagen de la ciudad como marco idóneo de integración política, con todo lo que, naturalmente, suponía de creación una falsa imagen de la ciudad como escenario ficticio de unanimidades, que sin duda no era ajena a las necesidades de propaganda y legitimación de las oligarquías dominantes en cada caso, interesadas en ocultar las tensiones internas de índole tanto social como política en curso, consustanciales a la vida de las ciudades de fines del medievo (nota 90).

Con todo, las ciudades castellanas bajomedievales, de acuerdo con los intereses de sus oligarquías, en su doble perspectiva de relación con el gobierno general del reino y, por otro lado, de dominación política y social en el marco local y concreto de la propia ciudad, protagonizaron la creación de un conjunto de mensajes ideológicos, caracterizados por experimentar un continuado proceso de diversificación y que respondieron a objetivos y formas expositivas coherentes 
Fragmentos de ideología política urbana en la castilla bajomedieval

con los distintos contextos que se sucedieron en la convulsa historia política castellana desarrollada durante los siglos bajomedievales, en la que la consideración de tales discursos ideológicos urbanos aporta algunos elementos de comprensión significativos de su propia evolución. 
1. Me refiero al trabajo de María ASENJO GONZÁLEZ, «Las ciudades» en Orígenes de la Monarquía Hispánica. Propaganda y Legitimación (1400-1520), dir. por J. M. Nieto Soria, Madrid, 1999, pp. 105140 , en donde, a la vez que se ofrece una detallada contextualización en el marco europeo, se abordan preferentemente las expresiones simbólicas y ceremoniales del poder concejil en la Castilla de fines del medievo, pudiéndose hallar en dicho trabajo una extensa base bibliográfica para el análisis de tales cuestiones.

2. Desde esta perspectiva puede encontrarse un estado de la cuestión a partir bibliografía reciente relacionada con tal tema en: José Manuel NIETO SORIA, «Ideología y poder monárquico en la Península», en La Historia Medieval en España. Un balance historiográfico (19681998) [XXV Semana de Estudios Medievales de Estella], Pamplona, 1999, pp. 335-381.

3. En esta línea de enfoque general sobre la práctica ceremonial urbana en la Corona de Castilla puede verse: Gema PALOMO FERNÁNDEZ y José Luis SENRA GABRIEL Y GALÁN, «La ciudad y la fiesta en la historiografía castellana de la Baja Edad Media: escenografía lúdico-festiva», Hispania, 54/1, 186 (1994), 5-36.

4. Referencias bibliográficas abundantes sobre la práctica ceremonial urbana en la Castilla bajomedieval pueden encontrarse en los trabajos que se acaban de citar. Un estudio monográfico reciente sobre un caso particular: Juan José CAPEL SÁNCHEZ, La vida lúdica en la Murcia bajomedieval, Murcia, Murcia 2000, en especial, pp. 145-178.

5. En efecto, en este trabajo me limitaré a la valoración de textos escritos, debiendo venir de su análisis interrelacionado como mani- 


\section{Fragmentos de ideología política urbana en la castilla bajomedieval}

festaciones simbólicas y ceremoniales lo que habría de ser una visión completa de estos fundamentos ideológicos del poder concejil.

6. José María MíNGUEZ FERNÁNDEZ, «Las hermandades generales de los concejos en la Corona de Castilla (objetivos, estructura interna y contradicciones en sus manifestaciones iniciales)», en Concejos $y$ ciudades en la Edad Media hispánica, [II Congreso de Estudios Medievales de la Fundación Sánchez-Albornoz], Madrid, 1990, p. 551.

7. Entre los trabajos más recientes relativos al tema, en el que se puede hallar extensa y detallada información sobre la evolución historiográfica del mismo, puede verse: María ASENJO GONZÁLEZ, «Ciudades y hermandades en la Corona de Castilla. Aproximación sociopolítica», Anuario de Estudios Medievales, 27/1 (1997), pp. 103-146.

8. Así, por ejemplo, en la ordenanza del concejo de Cuenca en la que establece quién deberá custodiar el sello de la ciudad y los derechos que se han de percibir por su uso: «Todos abenidos, fazemos estableçimiento de nuestros sellos...» (Cuenca, 14 de noviembre de 1280). F. Antonio CHACÓN GÓMEZ-MONEDERO, Colección diplomática del concejo de Cuenca, 1190-1417, Cuenca, 1998, doc. 19, p. 102; también en ibid., doc. 36.

9. "Otrossí, qualquier que sea del cuerpo de la villa o de las aldeas», Ibid., doc. 19.

10. Así puede verse en una carta del concejo de Chinchilla al infante don Sancho, en la que le ratifica su fidelidad: «Et porque entendemos que es seruiçio de Dios et del rey uostro padre et de uso et enderaçamiento de toda la tierra que pidades merçet por nos et por todos los 
de la tierra a nostro señor el rey uostro padre, que nos mantenga los buenos fueros et bonos usos et costumbres que ouiemos con el rey don Ferrando uostro auuelo» (Chinchilla, 11 de mayo de 1281). Juan TORRES FONTES, Documentos del siglo XIII, «Colección de documentos para la historia del reino de Murcia», II, Murcia, 1969, doc. LXXVII, pp. 70-71.

11. "E catastes siempre muy verdaderamente toda nuestra pro, toda nuestra honra e acrecentamiento de los nuestros términos...» (Cuenca, 17 de mayo de 1281), CHACÓN GÓMEZ-MONEDERO, Colección diplomática del concejo de Cuenca, doc. 21.

12. "Otrosi que guardemos todos nuestros fueros e usos e costumbres e priuilegios e cartas e todas nuestras libertades, franquezas siempre en tal manera que si el rey o el infante don Sancho o los otros reys que uernan después del e otros qualesquier sennores o alcalles $o$ merinos o otros qualesquier ommes nos quisieren pasar contra ello en todo o en parte dello o en qual guisa quier o en qualquier tiempo que seamos todos unos e enuiarlo decir al rey o a don Sancho o a los reys que uernan después dellos asi como el priuilegio dice e aquello que fuere a nuestro agrauamiento e si ellos la quisieren endereçar e si non que seamos todos unos a defendernos e ampararnos asi como dice el priuilegio que nos dio nuestros (sic) sennor el infante don Sancho» (Valladolid, 8 de julio de 1282). Es el compromiso de ayuda mutua entre la hermandad de León y Galicia y la de Castilla al concejo de Nájera. César GONZÁLEZ MíNGUEZ, «Aproximación al estudio del 'movimiento hermandino' en Castilla y León», Medievalismo. Boletín 


\section{Fragmentos de ideología política urbana en la castilla bajomedieval}

de la Sociedad Española de Estudios Medievales, 2 (1992), doc. I, p. 55.

13. "Bien creemos que sabedes en commo nos siempre trabaiamos en seruir et en ayudar de buen coraçon a nuestro señor el rey en todas las cosas que nuestro seruicio ouo mester, mayormientre en este fecho de la grant falsedad que fizieron contra el, en que se le alçaron con su tierra, negando el señorío que auíe sobrellos et robandol todo lo suyo o quier que lo el auíe, et prendiendo et matandol todos sus omnes, et tolliendoles quanto les fallauan, assí que de todo derecho et de toda naturaleza se parieron que auíen con el» (Sevilla, 8 de enero de 1283). TORRES FONTES, Documentos del siglo XIII, doc. LXXIX, p. 73.

14. «Sepan quantos esta carta vieren como por muchos desafueros sin seer oidos, e deshonras e otras muchas cosas sin guisa que eran contra justicia e contra fuero, e a gran danno de todos los regnos de Castiella, de Toledo, de León (...) que recebimos del rey don Alfonso, fijo del rey don Fernando, e más del rey don Sancho, su fijo, que agora fue, fasta este tiempo en que regnó nuestro señor el rey don Fernando, que nos otorgó e confirmó nuestros fueros et nuestos privilegios, e nuestras cartas, e nuestros buenos usos, e nuestras cartas, e nuestros buenos usos, e nuestras buenas costumbres, e nuestras libertades que obviemos en tiempos de los otros reyes quando los meyor oviemos. Por ende, e por mayor asesego de la tierra, e mayor guarda del so señorío, para esto guardar e mantener, e porque ninguna en ningún tiempo sea quebrantada, e creyendo que es a servicio de Dios e de Santa María, et de la corte celestial, e a servicio e a honra e a 
guarda de nuestro señor el rey Don Fernando, a quien dé Dios buena vida e salut, por muchos años e buenos, e mantenga a so servicio. Et otrosi a servicio, e a honra, e a guarda de los otros reyes que serán después dél, e a pro e guarda de toda la tierra facemos hermandad en uno nos todos los conceios del regno de Castiella (...) Otrosi que guardemos todos nuestros buenos fueros, e buenos usos, e buenas costumbres, e privileios, e cartas, e todas nuestras libertades e franquezas siempre en tal manera que si el rey don Fernando, nuestro señor, ó los otros reyes que vernan después dél, o otros qualesquier sennores, o alcallde, o merino, o otros qualesqier omes nos quisiesen pasar contra ello en todo, o en parte dello en qualquier guisa,e en qualquier tiempo, que nos que seamos todos unos a enviarlo mostrar a nuestro señor el rey, o a los reyes que vernan después dél, aquello que fuer a nuestro agravamiento, e si ellos lo quisieren enderezar, e si non que seamos todos unos a ge lo defender e ampararlo, asi como dice en el privileio que nos dio nuestro señor el rey don Sancho quando tomó la voz con todos los de la tierra, guardando la persona de nuestro señor el rey» (Burgos, 6 de julio de 1295). Carta de hermandad de los concejos de Castilla. Antonio BENAVIDES, Memorias de don Fernando IV de Castilla, II, Madrid, 1860, doc. III, pp. 3-4.

15. Ibid., p. 4, y expresión similar en la carta de hermandad de los concejos de León y de Galicia suscrita con motivo de las cortes celebradas en Valladolid (12 de julio de 1295). Ibid., doc. IV

16. "Todos abenidos en un coraçón et de una sana voluntad, a serviçio de Dios et de Sancta María et de nuestro señor, el rey» (Cuenca, 


\section{Fragmentos de ideología política urbana en la castilla bajomedieval}

10 de abril de 1296). CHACÓN GÓMEZ-MONEDERO, Colección diplomática..., doc. 36 .

17. Cortes de los antiguos reinos de León y Castilla, I, Madrid, 1861, p. 248.

18. "Sepan quantos esta carta vieren, commo nos, el conçeio de la noble çibdat de Baeça, e nos, el conçeio de Ubeda, seyendo en uno ayuntados a una voluntad, e seyendo de commo avemos reçebido muchos agravios e muchos males de muchas partes, e en muchas mañas (...) et porque nuestro señor el rey don Alfonso es pequeño e sin edat, e non aya en la tierra a quien lo podamos querellar, que nos pueda y poner cobro de los males e los daños, que avemos reçebido e reçebimos de cada día, e tenemos de reçebir más cab adelante. Et por guardar juicio de Dios e de nuestro señor el rey. Et porque entendemos que es pro e guarda de la tierra, e que nos es mucho menester» (21 de noviembre de 1319). Carta de hermandad entre los concejos de Báeza y Úbeda. María A. MORENO MORENO, Las cartas del concejo de Baeza (siglos XIV-XVI), Jaén, 2000, pp. 75-78.

19. «Por nuestros pecados, nuestro Señor Dios quiso levar deste mundo al rey don Fernando», CHACÓN GÓMEZ-MONEDERO, Ob. Cit., doc. 49.

20. Antonio C. FLORIANO, Documentación histórica del archivo municipal de Cáceres (1229-1471), Cáceres, 1987, doc. 40 (Cáceres, 31 de marzo de 1328), en documento referido al acuerdo del concejo de Cáceres para no recibir a juez de salario ni alcalde enviados por el rey sin que hubiera previa petición del concejo. 
21. José Manuel NIETO SORIA, Ceremonias de la realeza. Propaganda y legitimación en la Castilla Trastámara, Madrid, 1993.

22. Una reunión de trabajos referentes a distintos marcos políticos en: Barbara A. HANAWALT y Kate L. REYERSON (ed.), City and spectacle in Medieval Europe, Minneapolis, 1994.

23. BIBLIOTECA NACIONAL DE MADRID, ms. 13.100, fols. 168r172 .

24. NIETO SORIA, Ceremonias de la realeza, pp. 65-67.

25. Véanse a modo de ejemplo el juramento realizado por los procuradores de las ciudades a la princesa doña María como sucesora al trono en 1402, en el que se incorporar referentes de estabilización de los vínculos políticos tales como los que quedan expresados en las siguientes frases: «leales, servidores, súbditos e vasallos e omenageros (...) las leyes del reyno que son las leyes de las Partidas (...) et alguna cosa fallecieren (...) que la yra de Dios (...) e seamos por ello traydores connosçidos». FLORIANO, Ob. Cit., doc. 69. Independientemente del carácter formulario de tales expresiones, no dejaban de definir los recursos retóricos mediante los que en el universo mental de la época permitían definir el vínculo entre el heredero del trono y las ciudades del reino.

26. Algunos ejemplos locales: Antonio ROMERO ABAO, Las fiestas de Sevilla en el siglo XV, Madrid, 1991 y María de los Llanos MARTíNEZ CARRILLO, «Fiestas ciudadanas: componentes religiosos y profanos de un cuadro Medieval (Murcia)», Miscelánea Medieval Murciana, 16 (1990-1991), pp. 9-50. 


\section{Fragmentos de ideología política urbana en la castilla bajomedieval}

27. José Manuel NIETO SORIA, Fundamentos ideológicos del poder real en Castilla (siglos XIII-XVI), Madrid, 1988, pp. 139-145.

28. José Manuel NIETO SORIA, «La transpersonalización del poder real en la Castilla bajomedieval», Anuario de Estudios Medievales, 17 (1987), pp. 559-570.

29. Cortes, II, p. 28, pet. 48.

30. Petición de esta índole, entre otras: Cortes, II, p. 329, pet. 17.

31. Benjamín GONZÁLEZ ALONSO, «Poder regio y régimen político en la Castilla bajomedieval (1252-1274)», Las Cortes de León en la Edad Media, II, Valladolid, 1988, p. 248.

32. José Manuel NIETO SORIA, Legislar y gobernar en la Corona de Castilla: el Ordenamiento Real de Medina del Campo de 1433, Madrid, 2000, pp. 62-71.

33. "Que todos los tres estados de vuestros regnos e mas aun el nuestro de las çibdades e villa». Cortes, III, p. 382, pet. 6 .

34. Juan Manuel CARRETERO ZAMORA, Cortes, monarquía, ciudades. Las Cortes de Castilla a comienzos de la época moderna (14761515), Madrid, 1988, pp. 48-49.

35. "Commo procuradores e en boz de los dichos vuestro regnos». Cortes, III, p. 497. "En nombre de los pueblos de vuestros rreynos e por nos otros». Cortes, III, p. 766.

36. CARRETERO ZAMORA, Ob. Cit., pp. 43-60. 


\section{José Manuel Nieto Soria}

37. Con relación al desarrollo de esta máxima: José Antonio MARAVALL, Estado moderno y mentalidad social. Siglos XV-XVII, I, Madrid, 1972, pp. 281 y sigs.

38. Véanse al respecto las consideraciones recogidas en: Salustiano de DIOS, Gracia, merced y patronazgo real. La Cámara de Castilla, 1474-1530, Madrid, 1993, pp. 101-102, y GONZÁLEZ ALONSO, «Poder regio, Cortes y régimen político», pp. 252-252 y, del mismo autor, «De Briviesca a Olmedo», En El Dret Comú i Catalunya, edic. de A. Iglesia Ferrerirós, Barcelona, 1995, pp. 66-70.

39. Cortes, III, p. 406.

40. Ibid., III, pp. 406-407.

41. Salustiano de Dios, «El ejercicio de la gracia en Castilla entre 1250 y 1530. Los inicios del Consejo de la Cámara», Anuario de Historia del Derecho Español, LX (1990), pp. 323-351.

42. "Commo suplicando e faziendo nuestras muy omildes peticiones a vuestra alteza». Cortes, III, p. 382, pet. 6. "Con quanta justicia e humilldad e deuida reuerençia podemos e devemos, le suplicamos en nombre de los dichos reynos». Ibid., III, p. 496, pet. 1.

43. Tras afirmar que "con toda rreuerençia fidelidad subjeçion obidiençia e lealtad los vasallos subditos e naturales deuen ser tenudos e obligados seruir temer amar onrrar obedesçer e guardar asu rrey e sennor natural, asi commo aquel que tiene logar de Dios enla tierra e es puesto por cabeça e sennor dellos, asy commo el rrey o prinçipe o otro qual quier soberano sennor que tal logar tiene», se manifiesta que el rey, como "soberano sennor» está obligado "segunt Dios e 


\section{Fragmentos de ideología política urbana en la castilla bajomedieval}

rrazon, trabajar, procurar con todas sus fuerzas, buscando catando e açeptando todas las vias e maneras e rremedios a el posibles por quitar delos rregnos e pueblos que por Dios les son encomendados, todas discordias e inconuinientes e los traer e rreduzir atoda unidat concordia e paz». Para ello deberá valerse «non sola mente delas muy altas virtudes dela justiçia e prudençia, mas aun eso mesmo dela misericordia, e non menos dela loable paçiençia, tolerando muchas cosas e condeçendiendo aellas por bien de paz; todo esto afyn quela cosa publica sea rregida en toda buena poliçia e gouernada e sostenida en verdat e justiçia». Cortes, III, p. 369.

44. Benjamín GONZÁLEZ ALONSO, «De Briviesca a Olmedo (algunas reflexiones sobre el ejercicio de la potestad legislativa en la Castilla bajomedieval)», 73-74 y José Manuel NIETO SORIA, «El 'poderío real absoluto' de Olmedo (1445) a Ocaña (1469): la monarquía como conflicto», En la España Medieval, 21 (1998), pp. 181-183.

45. "Quela principal cosa en que se deuee proueer e mas puede aprouechar es que vuestra merced esté poderoso e fuerte, teniendo cabdal de dineros». Cortes, III, p. 498.

46. «Ha dado e mandado dar algunas cartas e prouisiones por las que les absuelue e quita su derecho a alguna delas partes, e da por ninguno e rreuoca todo lo proçesado, e manda alos juezes que non proçedan nin vayan adelante por las dichas cabsas e pleytos e quelas dichas partes non sean mas oydas a su derecho e justiçia, e mande vuestra alteza que se faga e cunpla asi de vuestro propio motu e poderio rreal absoluto e con otras exorbitançias, non seyendo las dichas cartas e prouisiones vistas nin acordadas en vuestro Consejo, nin 
rrefrendadas enlas espaldas delos de vuestro Consejo segund que se rrequiere, lo qual es en grand deseruiçio vuestro e danno dela rrepublica de vuestros rregnos e de vuestros subditos e naturales e en grand cargo de vuestra conçiençia, e por ello peresçe su derecho alas partes e les es quitado». Cortes, III, p. 668, pet. 24.

47. Reproduzco textualmente los principios señalados sobre el citado memorial por Juan Ignacio GUTIÉRREZ NIETO, «Semántica del término 'comunidad' antes de 1520: las asociaciones juramentadas de defensa», Hispania, XXXVII-136 (1977), p. 346.

48. «Pero la verdad una es, conuiene a saber, aquella que tiene y sigue la muy noble y muy leal y santa çiudad de Toledo, como es fuerça e ayuda de sus valedores y defensores que son el Rey de los Reyes y la Reyna de los çielos». Eloy BENITO RUANO, Los orígenes del problema converso, Barcelona, 1976, pp. 104-105.

49. Ibid., p. 109.

50. Ibid., p. 112.

51. Ibid., p. 120.

52. Ibid., p. 121.

53. Cortes, III, pp. 675-676.

54. Ibid., III, pp. 701-702.

55. Ibid., III, p. 676.

56. Ibid., III, p. 707. 


\section{Fragmentos de ideología política urbana en la castilla bajomedieval}

57. Sobre el significado y evolución de esta cláusula, tan vinculada al ejercicio de la potestad legislativa del rey: Benjamín GONZÁLEZ ALONSO, "La fórmula 'obedézcase, pero no se cumpla' en el Derecho castellano de la baja Edad Media», Anuario de Historia del Derecho Español, 50 (1980), pp. 469-488. La alusión que ahora se hace con cierta reiteración reivindicativa por parte de los procuradores a la aplicación de esta fórmula para una amplia diversidad de cartas, en realidad, está poniendo de relieve el importante número de ellas en las que el rey está actuando contra derecho en aplicación de su poder absoluto.

58. Cortes, III, p. 732.

59. Ibid., III, pp. 732-734.

60. Así se comprueba en la aceptación por el concejo de Segovia de constituir una hermandad concejil a instancias del monarca, considerándose desde el concejo las siguientes razones para aceptar tal propuesta regia: «E por nos, el dicho conçejo, veyendo ser seruyçio del dicho Señor Rey, e prouecho e utilidad de sus Regnos, e clarificación de la su Justicia, fue obedecida e conplida la dicha carta, respondimos cómo estauamos prestos de le dar fauor e ayuda e de faser todo lo otro en la dicha carta contenydo». Julio PUYOL, Las hermandades de Castilla y León, Madrid, 1913, pp. 53-54.

61. V. LÓPEZ FERREIRO, Galicia histórica. Colección diplomática, I, pp. 19-27, citado por GUTIÉRREZ NIETO, Art. Cit., p. 345.

62. Es el juramento y pleito-homenaje de los caballeros de Toledo ante el arzobispo de Sevilla, enviado por el rey para pacificar la ciudad 
de Toledo. Eloy BENITO RUANO, Toledo en el siglo XV. Vida política, Madrid, 1961, doc. 31.

63. Julio PUYOL, Ob. Cit., pp. 106-125.

64. José Manuel NIETO SORIA, «Enrique IV de Castilla y el Pontificado (1454-1474)», En la España Medieval, 19 (1996), pp. 167-238.

65. «Otrosy, por que a Dios Nuestro Señor plega conseruar e aumentar esta Sancta hermandat, hordenamos e mandamos que se faga una procesión en cada una çibdat e villa e lugar e quarto de ochauo e seísmo e valle e alfos, para el segundo domingo que se contará honse dias del mes de Octubre, a la qual uayan todos los vesinos e moradores de las dichas çibdades lo mas deuotamente que pudieren, con candelas ençendidas, cada uno rogando a Nuestro Señor que le plega dar su esfuerço a esta dicha sancta hermandat e la conseruar por luengos tyenpos, por el bien destos Regnos, la qual mandamos que se faga, so pena de dies myll marauedis a cada çibdat e villa e lugar». Ibid., p. 124.

66. PUYOL, Ob. Cit., pp. 120-121.

67. GUTIÉRREZ NIETO, Art. Cit., pp. 344-350.

68. Se trata de dos cuadernos dados en Medina del Campo, y otros tres dados en Fuensalida, Cantalapiedra y Madrigal, descubiertos, publicados y comentados por José Luis BERMEJO CABRERO, «Hermandades y comunidades de Castilla», Anuario de Historia del Derecho Español, 58 (1988), 277-412.

69. Ibid., pp. 306-308. 


\section{Fragmentos de ideología política urbana en la castilla bajomedieval}

70. Ibid., pp. 328-329.

71. Esta conexión entre los móviles de la hermandad y las argumentaciones de las Cortes de Ocaña de 1469 ya fue observado en Ibid., p. 308.

\section{Cortes, III, pp. 767-769.}

73. Entre las demandadas concejiles estaba la reforma de la Audiencia Real para garantizar el funcionamiento de la justicia regia (Cortes, III, pp. 768-769), también dependiente de las actuaciones del Consejo Real, y así consiguieron que se redactasen nuevas ordenanzas relativas al Consejo Real, aunque resultaron de escasa efectividad, pues no resolvieron la práctica paralización en la que había caído la institución en estos años posteriores a la guerra civil y ya hasta el final del reinado. Estas ordenanzas pueden verse en: Salustiano de DIOS, Fuentes para el estudio del Consejo Real de Castilla, Salamanca, 1986, pp. 55-62. Sobre la inoperancia del Consejo Real en los últimos años del reinado, del mismo autor, El Consejo Real de Castilla (13851522), Madrid, 1982, pp. 136-139.

74. Ya observó la contradicción entre las Cortes de Ocaña y los pactos alcanzados por el rey con algunos grandes $\mathrm{M}^{\mathrm{a}}$ Isabel del VAL VALDIVIESO, «Resistencia al dominio señorial durante los últimos años del reinado de Enrique IV», Hispania, XXXIV (1974), p. 56.

75. Con motivo de las Cortes celebradas en Santiago-La Coruña en 1518 se reivindicaría por los procuradores de las ciudades allí reunidos buena parte del proyecto político planteado en Ocaña. Cortes, IV, p. 261. 
76. Jesús Luis CASTILLO VEGAS, Política y clases medias. El siglo XV y el maestro salmantino Fernando de Roa, Valladolid, 1987,

77. Juan Ignacio GUTIÉRREZ NIETO, «Puntos de aproximación en torno al movimiento hirmandino (relaciones entre la Santa Hermandad y la Santa Hirmandade)», Actas de las I Jornadas de metodología aplicada de Ciencias Históricas, vol. II: «Historia Medieval», Santiago de Compostela, 1975, p. 318.

78. Adeline RUCQUOI, «Des villes nobles pour le Roi», en Realidad e imágenes del poder. España a fines de la Edad Media, coord. A. Rucquoi, Valladolid, p. 198.

79. Joseph O'CALLAGHAN, «Sobre la promulgación del Especulo y del Fuero Real», Estudios en Homenaje a Don Claudio SánchezAlbornoz en sus 90 años, III (Anexos de Cuadernos de Historia de España), Buenos Aires, 1985, pp. 167-179.

80. Teófilo F. RUIZ, «The transformation on the Castilian municipalities: the case of Burgos, 1248-1350», Past and Present: A Journal of Historical Studies, 77 (1977), pp. 3-32.

81. Así lo señaló Miguel Ángel LADERO QUESADA, «Monarquía y ciudades de realengo en Castilla, Siglos XII al XV», Anuario de Estudios Medievales, 24 (1994), p. 758, añadiendo que tal toma conciencia se producía «en el marco común del reino, de modo que el sentimiento de patria local y el general — ser natural de Castilla_ estaban plenamente fundidos».

82. Cortes, II, p. 145, pet. 1. 


\section{Fragmentos de ideología política urbana en la castilla bajomedieval}

83. Miguel Ángel LADERO QUESADA, Lecturas sobre la España histórica, Madrid, 1998, pp. 177-212.

84. Así lo señala A. RUCQUOI, «Les villes nobles pour le roi», p. 197.

85. Ya se pronunciaba el obispo de Burgos Alonso de Cartagena al respecto, al afirmar que "este título no es superfluo, mas trae sus preeminencias, ca, quando se ayuntan las Cortes generales, las muy nobles cibdades tienen los primeros grados en el asentamiento e primeras boses en el fablar, guardadas las preeminencias de una a otra; e así se fase en las villas». Cita tomada de Juan A. BONACHÍA HERNANDO, «'Mas honrada que ciudad de mis reinos...' La nobleza y el honor en el imaginario urbano (Burgos en la Baja Edad Media)», en La ciudad medieval. Aspecto de la vida urbana en la Castilla bajomedieval, coord. por J. A. Bonachía, Valladolid, 1996, p. 181.

86. BONACHÍA HERNANDO, Art. Cit., en especial, pp. 171-172 y 211212.

87. El tema de la evolución ideológica del poder real durante la época de Isabel I lo he abordado en mi trabajo: «Fundamentos ideológicos del poder real en tiempos de Isabel I de Castilla», en Isabel la Católica y la política, Actas del Congreso organizo por el Instituto Universitario de Historia Simancas, Valladolid, 2001 (en prensa).

88. Así, con motivo de las Cortes de Valladolid de 1506, se plantearán exigencias de los concejos demandando mayor intervención en la práctica legislativa, pidiendo ser consultados para cualquier innovación legal y oponiéndose con particular rotundidad al extendido 
recurso a las pragmáticas de que había hecho cada vez más gala los monarcas castellanos desde tiempos de Juan II: "E quando leys se obieren de hazer, manden llamar sus rreynos e procuradores dellos, por que para las tales leys sean dellos muy mas enteramente informados y vuestros rreynos justa e derechamente proveídos». Cortes, IV, p. 225 , pet. 6 .

89. Véanse al respecto, con relación a las prácticas propagandísticas y legitimadoras de la nobleza: $M^{a}$ Concepción QUINTANILLA RASO, «La nobleza», en Orígenes de la Monarquía Hispánica. Propaganda y Legitimación, pp. 62-103 y, de la misma autora, «El orden señorial y su representación simbólica: ritualidad y ceremonia en Castilla a fines de la Edad Media», Anuario de Estudios Medievales, 29 (1999), pp. 843-973. Sobre el discurso nobiliario con respecto a la monarquía: José Manuel NIETO SORIA, «La realeza caballeresca en la Castilla de medidados del siglo XV: representación literaria y formalización jurídico-política», en La chevalerie en Castille à la fin du Moyen Age. Aspects sociaux, idéologiques et imaginaires, dir. Georges Martin, París, 2001, pp. 61-80.

90. Sobre esta relación entre construcción ideológica e intereses de las oligarquías urbanas en el marco de las tensiones sociales cotidianas puede verse: $M^{a}$ Isabel del VAL VALDIVIESO, «Aspiraciones y actitudes socio-políticas. Una aproximación a la sociedad urbana de la Castilla bajomedieval», La ciudad medieval: aspectos de la vida urbana en la Castilla bajomedieval, pp. 213-254. 